\title{
Anthropogenic acceleration of sediment accretion in lowland floodplain wetlands, Murray-Darling Basin, Australia
}

\author{
Peter Gell ${ }^{\mathrm{a}, *}$, Jennie Fluin ${ }^{\mathrm{b}, \mathrm{e}}$, John Tibby ${ }^{\mathrm{b}}$, Gary Hancock ${ }^{\mathrm{c}}$, Jennifer Harrison ${ }^{\mathrm{d}}$, Atun Zawadzki ${ }^{\mathrm{d}}$, \\ Deborah Haynes $^{\mathrm{e}}$, Syeda Khanum ${ }^{\mathrm{b}}$, Fiona Little ${ }^{\mathrm{e}}$, Brendan Walsh ${ }^{\mathrm{b}}$ \\ a School of Science and Engineering, The University of Ballarat, Vic, 3353 Australia \\ ${ }^{\mathrm{b}}$ Geographical and Environmental Studies, The University of Adelaide, South Australia, 5005, Australia \\ c CSIRO Land and Water, Black Mountain, ACT, 2601, Australia \\ d ANSTO, PO Box 1, Menai, NSW, 2234, Australia \\ e Geology and Geophysics, The University of Adelaide, South Australia, 5005, Australia
}

\section{Introduction}

Wetlands act as sediment sinks in catchments and so can be used as a means to establish mean sediment accumulation rates. The sediment input to lowland wetlands is potentially greater than their upland counterparts owing to the amplification of fluxes into higher order streams. The contribution of sediments carried by the main river to floodplain wetlands is influenced by the degree of connectivity between the river and the wetland and the frequency of floods of heights sufficient to connect the two. Allochthonous sources, which include direct inputs from the neighbouring floodplain, combine with endogenic production of sediments and organic matter that can further accelerate gross sediment accretion. The trajectory towards complete infilling may be balanced by declining sediment trapping efficiency as a wetland fills, and sediment scouring with high flow events. Human-induced increased flux of allochthonous sources down large rivers may come from surface erosion from the catchment, stream bank erosion and collapse and soil surface sodicity (Neave and Rayburg, 2006) and this may, at least in part, be balanced, in regulated

\footnotetext{
* Corresponding author.

E-mail address: p.gell@ballarat.edu.au (P. Gell).
}

systems, by sediment trapping behind impoundments (Olley and Wallbrink, 2004). Endogenic drivers that accelerate accretion rates include wave-driven erosion of exposed littoral zones (Bourman and Barnett, 1995) and increased sediment trapping by aquatic macrophytes promoted by accelerated nutrient fluxes (see Table 1 ).

This paper synthesizes reported evidence on the sedimentation rates of a range of wetlands down a river continuum in the Murray River catchment of Australia (Fig. 1). Dating techniques comprising optically stimulated luminescence (OSL), ${ }^{210} \mathrm{~Pb},{ }^{137} \mathrm{Cs},{ }^{14} \mathrm{C}$ AMS and exotic pollen biomarkers were used to establish chronologies from core sequences extracted from the wetlands. Diatom microfossils provide evidence for changing wetland condition. The timing of increases in river plankton in wetlands closely linked to the main channel was used to aid the identification of the onset of river regulation in the mid-1920s AD.

\section{Study area}

The Murray-Darling Basin covers $1.073 \times 10^{6} \mathrm{~km}^{2}$ and ranges from montane landscapes in the south-east that, in winter-spring, provide for most of the catchment runoff, to semi-arid and arid conditions in 
Table 1

Estimated change in mean sedimentation rates and water quality status in Murrumbidgee-Murray floodplain wetlands.

\begin{tabular}{|c|c|c|c|c|c|c|}
\hline \multirow[t]{2}{*}{ Wetland } & \multirow[t]{2}{*}{ Wetland type } & \multirow[t]{2}{*}{ Dating technique } & \multicolumn{2}{|c|}{ Sedimentation rate $(\mathrm{mm} / \mathrm{yr})$} & \multicolumn{2}{|c|}{ Water quality status change } \\
\hline & & & Baseline & Post impact & Salinity & Nutrients \\
\hline 1. Berri Jerri Lagoon ${ }^{\mathrm{a}}$ & Floodplain oxbow lake & Pollen ${ }^{210} \mathrm{~Pb},{ }^{137} \mathrm{Cs}$ & n.a. & 6 & $\Uparrow$ then $\Downarrow$ & $\Uparrow$ \\
\hline 2. Coonoocoocabil Lagoon ${ }^{\mathrm{a}}$ & Floodplain oxbow lake & Pollen ${ }^{210} \mathrm{~Pb},{ }^{137} \mathrm{Cs}$ & n.a. & 6 & $\Uparrow$ & $\Uparrow$ \\
\hline 3. Balranald Weir ${ }^{\mathrm{a}}$ & Weir & Pollen ${ }^{210} \mathrm{~Pb},{ }^{137} \mathrm{Cs}$ & n.a & 9 & $\Uparrow$ & $\Uparrow$ \\
\hline 4. Junction Park Billabong ${ }^{\mathrm{b}}$ & Floodplain oxbow lake & Pollen, ${ }^{14} \mathrm{C}$ (AMS pollen preparations & 0.7 & 3.8 & & $\Uparrow$ \\
\hline 5. Hopcrofts Billabong ${ }^{\mathrm{c}}$ & Floodplain oxbow lake & Pollen, ${ }^{14} \mathrm{C}$ (AMS pollen preparations) & $\sim 2$ & $\sim 5$ & & \\
\hline 6. Lake Cullulleraine $e^{\mathrm{b}, \mathrm{d}, \mathrm{e}}$ & Retention basin & ${ }^{210} \mathrm{~Pb}$ & n.a. & 5 & & \\
\hline 7. Tareena Billabong,f,f & Floodplain oxbow lake & Pollen, ${ }^{210} \mathrm{~Pb},{ }^{137} \mathrm{Cs}$, OSL, ${ }^{14} \mathrm{C}$, & 0.6 & $2-20$ & $\Uparrow$ & $\Uparrow$ \\
\hline 8. Ral Ral Creek ${ }^{g}$ & Floodplain oxbow lake & ${ }^{210} \mathrm{~Pb}$ & n.d. & 9.5 & n.d. & n.d. \\
\hline 9. Pikes Creek $^{g}$ & Floodplain oxbow lake & ${ }^{210} \mathrm{~Pb}$ & n.d. & 30 & n.d. & n.d. \\
\hline 10. Ajax Achilles ${ }^{\mathrm{h}}$ & Levee lake & ${ }^{210} \mathrm{~Pb}, \mathrm{OSL}$ & n.d. & $\sim 10$ & n.d. & n.d. \\
\hline 11. Loveday-Cobdogla Wetland ${ }^{i}$ & Floodplain oxbow lake & Pollen, ${ }^{210} \mathrm{~Pb},{ }^{137} \mathrm{Cs}$, OSL & 1.0 & 6 & $\Uparrow$ & $\Uparrow$ \\
\hline 12. Swanport Wetland ${ }^{g}$ & Levee swamp & Pollen & 1.2 & 17 & & $\Uparrow$ \\
\hline 13. Murroondi Wetland ${ }^{c}$ & Levee swamp & Pollen, ${ }^{137} \mathrm{Cs},{ }^{14} \mathrm{C}$ (AMS sediment) & 2.8 & $5-10$ & & $\Uparrow$ \\
\hline 14. Lake Alexandrina ${ }^{\mathrm{d}, \mathrm{j}, \mathrm{c}, \mathrm{h}}$ & Terminal lagoon & Pollen, ${ }^{210} \mathrm{~Pb},{ }^{14} \mathrm{C}$ (AMS sediment) & $0.3-0.7$ & 1.7 & $\Downarrow$ & $\Uparrow$ \\
\hline 15. Coorong North Lagoon ${ }^{\mathrm{j}}$ & Barrier lagoon & Pollen, ${ }^{137} \mathrm{Cs}$, ${ }^{14} \mathrm{C}$, OSL & $0.1-1.0$ & $1.0-8.8$ & $\Uparrow$ & $\Uparrow$ \\
\hline 16. Coorong South Lagoon ${ }^{\mathrm{j}}$ & Barrier lagoon & Pollen, ${ }^{137} \mathrm{Cs},{ }^{14} \mathrm{C}$, OSL & $0.1-1.0$ & $0.5-17.7$ & $\Uparrow$ & \\
\hline
\end{tabular}

n.a. not applicable, n.d. not determined (research ongoing).

a Gell and Little (2006).

b Adamson et al. (in preparation).

c Gell et al. (2005a).

d Fluin (2002).

e Reid et al. (2002)

${ }^{\mathrm{f}}$ Gell et al. (2005b).

g Gell et al. (2006).

h Khanum (unpublished data).

i Gell et al. (2007).

j Fluin et al. (2007).

the south-west. The northernmost extent of the catchment extends into sub-tropical climates that can provide sporadic high flows in summer-autumn. The catchment was settled from the 1840s and now provides $40 \%$ of Australia's agricultural gross domestic product, however this has come at vast environmental cost. In excess of $80 \%$ of the $14 \times 10^{9} \mathrm{Gl}$ mean annual discharge has been diverted for irrigation agriculture and domestic use (Commonwealth of Australia, 2001). In many lowland parts of the catchment saline regional groundwater tables are perennially within the capillary zone and large areas of the catchment have been impacted by secondary salinisation. Nutrients are released from urban sources, fertiliser application, irrigation return drains and from clays mobilised from exposed riverbanks. Stock grazing rates were high within a few years of settlement and the controlling influence of ENSO cycles has exacerbated erosion through extreme droughts and flood events. Widespread recognition of the degraded nature of the catchment has

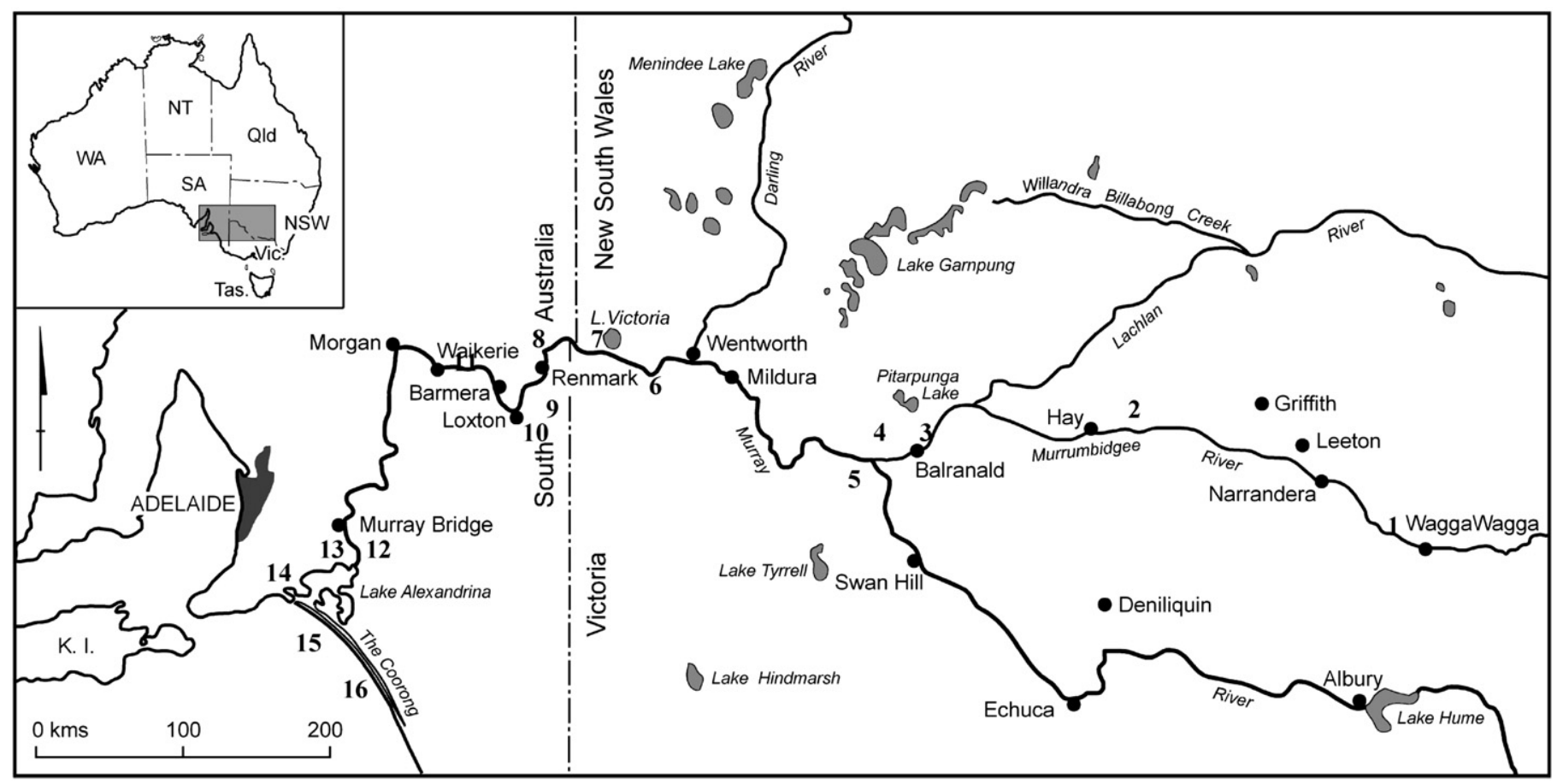

Fig. 1. The Murrumbidgee and Murray Rivers in south-eastern Australia. Site numbers correspond to those in Table 1. 
generated government and community-based measures to limit abstraction, reduce the flow of saline groundwaters, revegetate subcatchments and restore floodplain wetlands. The wetlands under study range from levee and oxbow lakes along the river floodplain to terminal lakes that owe their origin to the reduction in gradient and formation of barrier spits after the stabilisation of sea levels in the mid Holocene. Most floodplain wetlands are shallow $(<1 \mathrm{~m})$ and they tend to dry regularly. Some have been maintained by connection to weirs along the rivers and so are deeper $(1-3 \mathrm{~m})$. The terminal lakes are perennial and slightly deeper $(1-4 \mathrm{~m})$. The upper wetlands (Berri Jerri Lagoon to Pikes Creek) are within a broad floodplain while the lower wetlands (Ajax Achilles Lagoon to Murroondi) are within a gorge and lie between the main river channel and high, limestone cliffs.

\section{Methods}

Over the last decade over 40 floodplain and terminal wetlands within the Murray Darling Basin have been cored for paleolimnological research (Barnett, 1994; Thoms et al., 1999; Ogden, 2000; Reid et al., 2002; Tibby et al., 2003; Gell and Little, 2006; Gell et al., 2005a,b, 2006 , 2007; Fluin et al., 2007). Here, evidence from 16 wetlands along a river continuum from Wagga Wagga on the Murrumbidgee River to the Coorong at the mouth of the River Murray is selected to generate a regional synthesis to reveal broadscale wetland sedimentation rates, the challenges of radiometric dating of floodplain and terminal wetland sediments and to demonstrate the use of microfossil indicators to reveal generalised changes to river and wetland conditions. In most sites a Russian (d-section) corer (after Jowsey, 1966) was used to retain the depth/age profile but often a field piston corer (after Chambers and Cameron, 2001) was used to increase sediment volume for analysis. In several wetlands cores were taken from two or three locations. At several sites samples were taken for ${ }^{14} \mathrm{C}$ AMS dating. Elsewhere core chronology was supported using OSL dating. In most instances, recent samples were taken for alpha or gamma spectrometry to generate a ${ }^{210} \mathrm{~Pb}$ decay profile and to gain evidence for ${ }^{137} \mathrm{Cs}$ activity. Given the variable nature of the flux of sediments in fluvial, and particularly lowland, contexts, the constant initial concentration model (Walling et al., 2002) for ${ }^{210} \mathrm{~Pb}$ was usually applied to derive recent age-depth profiles and sedimentation rates. The upper sediments of most cores were sub-sampled to identify the arrival of Pinus pollen (after Ogden, 1996). The changing nature of the sediments in many cores was analysed utilising magnetic susceptibility analysis by passing unopened PVC cores through a Bartington BS2 loop. Subsamples were collected from all cores to extract fossil diatom algae to reconstruct changes in wetland condition according to the known preferences of species for salinity and nutrients. Samples were prepared and enumerated using standard methods (after Battarbee et al., 2001). Species identification was supported by reference to Krammer and Lange-Bertalot (1986, 1988, 1991a,b) and Witkowski et al. (2001). The ecological inferences from each species are based on van Dam et al. (1994), Gell (1997), Sonneman et al. (2000), Gell et al. (2002), Tibby (2004) and Tibby and Reid (2004).

\section{Results}

The cores extracted from many of the selected wetlands were only $0.5-2 \mathrm{~m}$ in length. Those taken from larger oxbows are longer, ranging from $4.6 \mathrm{~m}$ (Tareena Billabong) to $14 \mathrm{~m}$ (Murroondi Wetland). The stratigraphy of most floodplain wetland sediment sequences was continuous grey or grey-brown clay. In sites where surface salinity was high, the uppermost sediments were blackened, presumably through reduction of sulphurous salts. Otherwise, most sequences provided little stratigraphic evidence for changing sedimentation rates or wetland condition. The $14 \mathrm{~m}$ sequence extracted from Murroondi Wetland was an exception in that it showed transition from grey clay to a dark brown organic matrix with increasing detrital matter towards the surface, consistent with hydroseral shifts as the wetland filled with sediment (Gell et al., 2005a).

The longer term chronologies of several wetlands were determined using ${ }^{14} \mathrm{C}$ AMS (Table 1 ; wetland nos. $\left.4,5,7,13,14,15,16\right)$ and OSL $(7,10$, $11,15,16)$ dating. In some cases (e.g. 7,13) the radiocarbon results were implausible (Gell et al., 2005a), perhaps affected by the prevalence of carbonate in the landscape. Elsewhere, the radiocarbon analyses provided plausible chronologies and ages of wetland origin. At Tareena Billabong the chronology was greatly improved by several OSL dates (Gell et al., 2005b). These were on fine sand, but plausible dates were also retrieved from analyses on clay fractions. Most ${ }^{210} \mathrm{~Pb} /{ }^{137} \mathrm{Cs}$ sequences provided plausible chronologies for recent sediments despite the known challenges faced when applying these techniques in riverine landscapes. At Tareena Billabong the ${ }^{210} \mathrm{~Pb}$ sequence may have been influenced by the shift to salinities $>3 \mathrm{~g} / \mathrm{l}$ due to the desorbtion of ${ }^{226} \mathrm{Ra}$ (Hancock and Murray, 1996). In most Coorong sequences ${ }^{137}$ Cs activity persisted in sediments below the lowest point of ${ }^{210} \mathrm{~Pb}$ detection. High salinity and organic levels are known to mobilise ${ }^{137} \mathrm{Cs}$ and these conditions fit those in the modern Coorong. In two wetlands these recent chronologies were also well supported by OSL analyses on the clay fraction. In some samples however, there was insufficient luminescence to gain a plausible date. The results of some samples were verified by identical results from two laboratories, one utilising bulk sediment and the other single grains. In one sequence (wetland 11), aware of the influence of sediment pore water content on the radiation dose, dates were provided for both lake full, and lake dry, scenarios. In the absence of independent water level data this effectively provides additional error margins to the determined dates (Gell et al., 2007). The first evidence of Pinus pollen in the cores was compared to the ${ }^{210} \mathrm{~Pb}$ derived ages. In Tareena Billabong, pine pollen was identified from sediments considered to be equivalent to $\sim 1880 \mathrm{AD}$ however, in the Coorong sequences, the arrival of pine pollen was estimated to have been as late as the 1950s AD.

Due to the particular challenges inherent in dating sediment sequences from floodplain wetlands, the sedimentation rates are estimated based on the most plausible chronologies. The sedimentation rates reported here are, therefore, not definitive and, given the highly variable hydrologic context, may remain so until new techniques can be applied to this temporal 'blind spot' (Fitzsimmons et al., 2008). The typical pre-European settlement sedimentation rates are between 0.1 and $1.0 \mathrm{~mm} / \mathrm{yr}$. Unless the radiocarbon dates returned for Murroondi Wetland substantially underestimate the age of the basal sediments, then the baseline sedimentation for this wetland is 2-3 mm/yr (Gell et al., 2005a), probably augmented by the sediment trapping role of wetland macrophytes. In many wetlands recent sedimentation rates are near $10 \mathrm{~mm} / \mathrm{yr}$ and, at Pikes Creek, $30 \mathrm{~mm} / \mathrm{yr}$ (Gell et al., 2006). The estimated changes to net sedimentation rates ranged from two to three-fold increases to 20 fold in the floodplain lakes and 80 fold in the terminal wetlands of the Coorong (Fluin et al., 2007).

The fossil diatoms archived in sediments provide evidence of changing wetland condition. Taxa known to prefer salinity concentrations in excess of $3 \mathrm{~g} / \mathrm{l}$ became common components of the diatom flora at Tareena Billabong from $\sim 1880 \mathrm{AD}$ (Gell et al., 2005b). In the Murrumbidgee wetlands several planktonic forms widely known to inhabit eutrophic waters are restricted to the upper sediments, but in several instances, pre-dating the arrival of exotic Pinus pollen (Gell and Little, 2006). In the sediment sequences of wetlands close to the main river, a substantial rise in the abundance of Aulacoseira spp., planktonic diatoms abundant in the main river (Tibby and Reid, 2004) may mark the beginning of river regulation (sensu Reid et al., 2002). Taxa known to dominate in disturbed, turbid conditions became common elements of the diatom flora of several of the lowland wetlands from early European settlement. Both of the latter two groups however, have shown to be abundant in some of the wetlands for centuries before the arrival of European settlers. 


\section{Discussion}

Most wetlands along this Murrumbidgee-Murray River continuum exhibit pre-European sedimentation rates in the order of $0.1-1.0 \mathrm{~mm} / \mathrm{yr}$. Rates in excess of $1.0 \mathrm{~mm} / \mathrm{yr}$ occurred in large meanders that were scoured deeply in the mid-Holocene. In all sites with the dating strength to allow comparison, the post-European sedimentation rates increased, in some instances by almost two orders of magnitude. Early postEuropean sedimentation rates were as high as $20 \mathrm{~mm} / \mathrm{yr}$ in sites impacted by nearby sheep runs (Gell et al., 2005b). These declined post regulation owing to the trapping of coarser sediments behind weirs and reduced supply of mobile soils. Recent rates as high as $10-30 \mathrm{~mm} / \mathrm{yr}$ are occurring, possibly driven by the increased sensitivity of floodplain surfaces to erosion through drought and increased sodicity. Given the shallow nature of many wetlands, and the elimination of medium level floods (Jones et al., 2002), the terrestrialisation of wetlands is likely to proceed at a pace greater than wetland renewal.

Lowland, limestone-rich landscapes are challenging sites to derive robust sediment chronologies (Gell et al., 2005a). This is due to the episodic transport of sediment, elevated wetland salinity concentrations and natural and artificial wetting and drying regimes. Despite this, plausible chronologies can be established by utilising a range of dating techniques. These chronologies can be supported by the assembly of a set of paleorecords that identify regional patterns in microfossil assemblage changes. Once established, the arrival of exotic pollen biomarkers and switches to river plankton-dominated assemblages can be used as corroborative evidence to support independent radiometric-based time lines. The pursuit of additional, more definitive, chronometers, is a focus of future collaborative research (Fitzsimmons et al., 2008) and will allow for the refinement of estimated sedimentation rates and allow better analysis of the timing of change and responsiveness of systems relative to the pre-European settlement baseline.

Lowland systems aggregate the sediments, nutrients and salts derived from the impact of humans on landscapes up-catchment as well as those derived nearby. The interrelationships between salinisation, erosion and nutrient release (Prosser et al., 2001) make it difficult to attribute changes in sensitive microfossils to particular drivers of change, and so to particular changes in land use. The abundance of diatom species such as Cyclotella meneghiniana or Staurosirella pinnata may increase under combinations of higher water turbidity, salinity and nutrient concentrations. The expansion of calibration data sets linking diatom taxa with water quality and wetland habitat will increase the capacity to make inferences of change from diatom assemblages. The extension of the suite of organisms extracted from sediment sequences will better reveal the ecological impacts of this phase of accelerated sediment, salt and nutrient flux to floodplain wetlands.

\section{Conclusion}

The natural, pre-European settlement sedimentation rate in most wetlands examined in this review was low with some sites accumulating as much as $2-3 \mathrm{~mm} / \mathrm{yr}$. Sedimentation rates increased soon after settlement and, at some sites, continue to increase to the present. While regulation may be limiting the flux of sediments down the river channels, other allochthonous, as well as autochthonous material are the likely sources. The restoration, or even rehabilitation, of these wetlands needs to recognise the threat of accelerating terrestrialisation and will require an understanding of the main sources of sediment supply.

\section{Acknowledgements}

Chris Crothers drafted Fig. 1. Field assistants were too numerous to name but their efforts are appreciated. The research was supported by
ARC Linkage (with River Murray Catchment Water Management Board) grant number LP0560552 to PG; ARC Linkage (with South Australian Departments of Water, Land and Biodiversity Conservation and Environment and Heritage) grant number LP0667819 to PG, JT and David McKirdy; AINSE grant number AINGRA05062 to PG, the Murrumbidgee Catchment Management Authority; The University of Adelaide, Monash University, an Australian Postgraduate Award to JF, an Australian International Scholarship to SK and Adelaide University Science Faculty Scholarships to DH and FL.

\section{References}

Adamson, K., Tibby, J., Kershaw, A.P., in preparation. Long term water quality and vegetation patterns at Junction Park Billabong, Murray River, Australia, with special emphasis on European impact. Austral Ecol.

Barnett, E.J., 1994. A Holocene paleoenvironmental history of Lake Alexandrina, South Australia. J. Paleolimnol. 12, 259-268.

Battarbee, R.W., Jones, V.J., Flower, R.J., Cameron, N.G., Bennion, H., Carvalho, L., Juggins, S 2001. Diatoms. In: Stoermer, E.F., Birks, H.J.B., Last, W.M. (Eds.), Tracking Environmental Change Using Lake Sediments. Terrestrial, Algal and Siliceous Indicators, vol. 3. Kluwer Academic Publishers, Dordrecht, The Netherlands, pp. 155-202.

Bourman, R.P., Barnett, E.J., 1995. Impacts of river regulation on the terminal lakes and mouth of the River Murray, South Australia. Aust. Geogr. Stud. 33, 101-115.

Chambers, J.W., Cameron, N.G., 2001. A rod-less piston corer for lake sediments: an improved, rope-operated percussion corer. J. Paleolimnol. 25, 117-122.

Commonwealth of Australia, 2001. Australia: State of the Environment 2001. CSIRO, Canberra.

Fitzsimmons, K.E., Gell, P.A., Bickford, S., Barrows, T.T., Mooney, S.P., Denham, T.P., OZPACS contributers, 2008. The OZPACS database: a resource for understanding recent impacts on Australian ecosystems. Quat. Australasia 24, 2-6.

Fluin, J., 2002. A diatom-based palaeolimnological investigation of the lower Murray River, south eastern Australia. Ph.D. thesis, School of Geographical and Environmental Studies, Monash University, Victoria.

Fluin, J., Gell, P., Haynes, D., Tibby, J., 2007. Paleolimnological evidence for the independent evolution of neighbouring terminal lakes, the Murray Darling Basin, Australia. Hydrobiology 591, 117-134.

Gell, P.A., 1997. The development of a diatom data base for inferring lake salinity: towards a quantitative approach for reconstructing past climates. A. J. Bot $45,389-423$.

Gell, P., Little, F., 2006. Long term water quality changes in Murrumbidgee floodplain wetlands revealed by fossil diatom assemblages. In: Taylor, I.R., Murray, P.A., Taylor, S.G. (Eds.), Wetlands of the Murrumbidgee River catchment: Practical management in an altered environment. Fivebough and Tuckerbil Wetlands Trust, pp. 43-65.

Gell, P.A., Sluiter, I.R., Fluin, J., 2002. Seasonal and inter-annual variations in diatom assemblages in Murray River-connected wetlands in northwest Victoria, Australia. Mar. Freshw. Res. 53, 981-992.

Gell, P., Tibby, J., Fluin, J., Leahy, P., Reid, M., Adamson, K., Bulpin, S., MacGregor, A., Wallbrink, P., Hancock, G., Walsh, B., 2005a. Accessing limnological change and variability using fossil diatom assemblages, south-east Australia. River Res. App. 21, 257-269.

Gell, P., Bulpin, S., Wallbrink, P., Bickford, S., Hancock, G., 2005b. Tareena Billabong - a palaeolimnological history of an everchanging wetland, Chowilla Floodplain, lower Murray-Darling Basin. Mar. Freshw. Res. 56, 441-456.

Gell, P., Fluin, J., Tibby, J., Haynes, D., Khanum, S., Walsh, B., Hancock, G., Harrison, J., Little, F., 2006. Changing fluxes of sediments and salts as recorded in lower River Murray wetlands, Australia. In: Rowan, J.S., Duck, R.W., Werritty, A. (Eds.), Sediment Dynamics and the Hydromorphology of Fluvial Systems, vol. 306. Int. Ass. Hydrol. Sci. Publ., pp. 416-424.

Gell, P., Baldwin, D., Little, F., Tibby, J., Hancock, G., 2007. The impact of regulation and salinisation on floodplain lakes: the lower River Murray, Australia. Hydrobiology 591, 135-146.

Hancock, G.J., Murray, A.S., 1996. The source and distribution of dissolved radium in the Bega River estuary, southeastern Australia. Earth Planet. Sci. Lett. 138, 145-155.

Jones, G., Hillman, T., Kingsford, R., MacMahon, T., Walker, K., Arthington, A. Whittington, J., Cartwright, S., 2002. Independent Report of the Expert Reference Panel on Environmental Flows and Water Quality Requirements for the River Murray System. CRCFE, Canberra.

Jowsey, P.C., 1966. An improved peat sampler. New Phytol. 65, 245-248.

Krammer, K., Lange-Bertalot, H., 1986. Süsswasserflora von Mitteleuropa. Bacillariophyceae, Teil i: Naviculaceae. Gustav Fischer Verlag, Stuttgart.

Krammer, K., Lange-Bertalot, H., 1988. Süsswasserflora von Mitteleuropa. Bacillariophyceae Teil ii: Bacillariaceae, Epithemiaceae, Surirellaceae. Gustav Fischer Verlag, Stuttgart.

Krammer, K., Lange-Bertalot, H., 1991a. Süsswasserflora von Mitteleuropa. Bacillariophyceae Teil iii: Centrales, Fragilariaceae, Eunotiaceae. Gustav Fischer Verlag, Stuttgart.

Krammer, K., Lange-Bertalot, H., 1991b. Süsswasserflora von Mitteleuropa. Bacillariophyceae Teil iv: Achnanthaceae. Gustav Fischer Verlag, Stuttgart.

Neave, M., Rayburg, S., 2006. Salinity and erosion: a preliminary investigation of soil erosion on a salinized hillslope. In: Rowan, J.S., Duck, R.W., Werritty, A. (Eds.), Sediment Dynamics and the Hydromorphology of Fluvial Systems, vol. 306. Int. Ass. Hydrol. Sci. Publ., pp. 531-539.

Ogden, R.W., 1996. The Impacts of Farming and River Regulation on Billabongs of the Southeast Murray Basin, Australia. Ph.D. thesis, Australian National University, Canberra. 
Ogden, R.W., 2000. Modern and historical variation in aquatic macrophyte cover of billabongs associated with catchment development. Regul. Rivers 16, 487-512.

Olley, J., Wallbrink, P., 2004. Recent Trends in Turbidity and Suspended Sediment Loads in the Murrumbidgee River, NSW, Australia, vol. 288. Int. Ass. Hydrol. Sci. Publication, pp. 125-129.

Prosser, I.P., Rutherfurd, I.D., Olley, J.M., Young, W.J., Wallbrink, P.J., Moran, C.J., 2001 Large-scale patterns of erosion and sediment transport in river networks, with examples from Australia. Mar. Freshw. Res. 52, 81-99.

Reid, M., Fluin, J., Ogden, R., Tibby, J., Kershaw, P., 2002. Long-term perspectives on human impacts on floodplain-river ecosystems, Murray-Darling Basin, Australia. Verh. Int. Verein. Theor. Ang. Limnol. 28, 710-716.

Sonneman, J., Sincock, A., Fluin, J., Reid, M., Newall, P., Tibby, J., Gell, P.A., 2000. An illustrated guide to common stream diatom species from temperate Australia. The Murray-Darling Freshwater Research Centre, Identification Guide No. 33.

Tibby, J., 2004. Development of a diatom-based model for inferring total phosphorus in south-eastern Australian water storages. J. Paleolimnol. 31, 23-36.
Tibby, J., Reid, M., 2004. A model for inferring past conductivity in low salinity waters derived from Murray River diatom plankton. Mar. Freshw. Res. 55, 587-607.

Tibby, J., Reid, M., Fluin, J., Hart, B.T., Kershaw, A.P., 2003. Assessing long-term pH change in an Australian river catchment using monitoring and palaeolimnological data. Environ. Sci. Technol. 37, 3250-3255.

Thoms, M.C. Ogden, R.W., Reid, M.A, 1999. Establishing the condition of lowland floodplain rivers: a palaeo-ecological approach. Freshw. Biol. 41, 407-423.

Van Dam, H., Mertens, A., Sinkeldam, J., 1994. A coded checklist and ecological indicator values of freshwater diatoms from the Netherlands. Neth. J. Aquat. Ecol. 28, 117-133.

Walling D.E. He, Q Appleby, P.G, 2002. Conversion models for use in soil-erosion, soilredistribution and sedimentation investigations. In: Zapata, F. (Ed.), Handbook for the Assessment of Soil Erosion and Sediment Using Environmental Radionuclides. Kluwer Academic Publishers, Dordrecht, The Netherlands, pp. 111-164.

Witkowski, A., Lange-Bertalot, H., Metzeltin, D., 2001. Diatom Flora of Marine Coasts 1. Iconographia Diatomologica, vol. 7. A.R.G. Gantner Verlag, Ruggell. 